\title{
SEED SEXING REVEALED FEMALE BIAS IN TWO RUMEX SPECIES
}

\author{
DAGMARA KWOLEK, ANDRZEJ J. JOACHIMIAK \\ Department of Plant Cytology and Embryology, \\ Institute of Botany, Jagiellonian University \\ Grodzka 52, 31-044 Kraków, Poland \\ e-mail: a.joachimiak@uj.edu.pl
}

(Received: March 25, 2010. Accepted: July 5, 2010)

\begin{abstract}
Sex-ratio bias in seeds of dioecious Rumex species with sex chromosomes is an interesting and still unsettled issue. To resolve gender among seeds of $R$. acetosa and $R$. thyrsiflorus (two species with an XX/XY $\mathrm{Y}_{2}$ sex chromosome system), this work applied a PCR-based method involving DNA markers located on Y chromosomes. Both species showed female-biased primary sex ratios, with female bias greater in $R$. acetosa than in $R$. thyrsiflorus. The observed predominance of female seeds is consistent with the view that the female biased sex ratios in Rumex are conditioned not only postzygotically but also prezygotically.
\end{abstract}

KEY WORDS: sex ratio, genetic marker, Rumex acetosa, Rumex thyrsiflorus, sex chromosomes, seeds.

\section{INTRODUCTION}

Sorrel (Rumex acetosa) is a dioecious plant with sex chromosomes (XX in females, $\mathrm{XY}_{1} \mathrm{Y}_{2}$ in males) (Parker and Clark 1991; Mosiołek et al. 2005). Female-biased sex ratios have been observed in natural populations of this species (for review see Korpelainen 2002; Błocka-Wandas et al. 2007). Similar aberrations are reported for some other species with the same sex chromosome system, belonging to the Rumex sect. Acetosa (Żuk 1963; Rychlewski and Zarzycki 1981; Stehlik and Barrett 2005).

In plants with chromosomal sex determination, the two sexes should be produced in equal numbers, so the deviation from a balanced sex ratio in $R$. sect. Acetosa has drawn the attention of many researchers. They have suggested different mechanisms to explain the higher frequency of females in populations: mortality of male-determining pollen during early gametophyte development, certation (competition between X- and Y-bearing gametophytes), differences between the sexes in germinability, and higher mortality of male embryos and plants (Correns 1928; Żuk 1970; Rychlewski and Zarzycki 1986; Korpelainen 2002; Stehlik and Barrett 2006; Stehlik et al. 2008).

The majority of authors agree that operational (i.e., observed at sexual maturity) highly female-biased sex ratios develop in Rumex populations gradually as the life stages proceed, mainly via greater mortality of males (Zarzycki and Rychlewski 1972; Korpelainen 2002; Stechlik et al. 2006). Still unresolved is the sex ratio in seeds produced in natural Rumex populations (primary sex ratio). It is very difficult to establish, and can result from different mechanisms which are not well documented, both prezygotic (male pollen mortality, certation) and postzygotic (abortion of male embryos). The relative contributions of all these mechanisms to female bias appears to be relatively small as compared with the greater mortality of male plants (Stehlik and Barrett 2005). Earlier studies of Rumex based on chromosome counts in germinal root tips of young seedlings (male $2 n=15$, female $2 n=14$ ) generally showed a slight excess of female seeds (Zarzycki and Rychlewski 1972; Rychlewski and Zarzycki 1981, 1986). Results obtained this way can be questioned, however, because of the lack of information about the sex of ungerminated seeds. Information on Y chromosome-specific DNA sequences in Rumex (Shibata et al. 1999; Stehlik and Blattner 2004) has been used to develop more convenient PCR-based methods of sexing sorrel seeds. Korpelainen (2002) showed that the primary sex ratio in Finnish populations of $R$. acetosa did not significantly differ from 1:1, and Stehlik and Barrett (2005) and Stehlik et al. (2008) revealed a small but evident female bias in seeds of alpine $R$. nivalis from Switzerland. The observed dissimilarity may conceivably be due to genetic differences between these plants: analysis of Y chromosome-specific sequences in $R$. nivalis showed a relatively large genetic difference between it and R. acetosa (Stehlik and Blattner 2004).

In this study we examined the primary sex ratio in $R$. acetosa L. and also in R. thyrsiflorus Fingerh., a third species of $R$. sect. Acetosa with a well documented operational female bias (Zarzycki and Rychlewski 1972; Rychlewski and Zarzycki 1981, 1986). R. thyrsiflorus is the closest relative of $R$. acetosa, often treated as a subspecies 
of it (R. acetosa subsp. thyrsiflorus (Fingerh.) Hayek). To determine the sex of seeds collected from natural populations, we chose RAY-f and RAY-r PCR primers (Korpelainen 2002), which amplify the male-specific RAYSI sequence present on the $\mathrm{Y}$ chromosomes of $R$. acetosa and its close relatives (Navajas-Peréz et al. 2006).

\section{MATERIALS AND METHODS}

\section{Plant material}

Seeds ( $\mathrm{n}=100$ for each population) were collected from natural populations of $R$. acetosa and $R$. thyrsiflorus in Poland (Table 1). Leaves of flowering male and female plants collected from the same population $(n=10$ for each sex) were the control material. Fresh or frozen leaves and seedlings were used for DNA extraction.

The two taxa are barely distinguishable; $R$. thyrsiflorus is commonly misidentified as $R$. acetosa. The main morphological difference concern the root system (taproot large, with remote secondary roots in $R$. thyrsiflorus vs. short, fibrous roots in $R$. acetosa). Moreover, in Poland two investigated species clearly differ in flowering time $-R$. acetosa blooms and fructify earlier than $R$. thyrsiflorus. Leaves/seeds of $R$. acetosa were collected in May/June, and leaves/seeds of $R$. thyrsiflorus in July/August.

\section{DNA extraction}

DNA was extracted from seeds and leaves by the CTAB method (Gawal and Jarret 1991) with modifications. Fresh or frozen leaves were ground in liquid nitrogen with a mortar and pestle. Approximately $100 \mathrm{mg}$ homogenous powder was mixed with $700 \mu$ l extraction buffer [4\% CTAB, 100 $\mathrm{mM}$ Tris- $\mathrm{HCl}$ (pH 8.0), $1.4 \mathrm{M} \mathrm{NaCl}, 20 \mathrm{mM}$ EDTA( $\left(\mathrm{Na}_{2}\right)$, $1 \%$ PVP, $0.1 \% \beta$-mercaptoethanol]. After incubation at $65^{\circ} \mathrm{C}$ for $20 \mathrm{~min}$., $600 \mu \mathrm{l}$ chloroform:isoamyl alcohol $(24: 1$ $\mathrm{v} / \mathrm{v}$ ) was added, and the samples were shaken for $10 \mathrm{~min}$. and centrifuged $(15,000 \mathrm{x}$ g, $10 \mathrm{~min}$.). DNA was precipitated by mixing the aqueous phase with $500 \mu$ isopropanol and centrifuging $\left(15,000 \mathrm{x}\right.$ g, $\left.10 \mathrm{~min} ., 4^{\circ} \mathrm{C}\right)$. The DNA pellet was washed with $500 \mu 170 \%$ ethanol, dried and dissolved in $50 \mu \mathrm{l}$ TE buffer [10 mM Tris- $\mathrm{HCl}(\mathrm{pH} 8.0), 1$ mM EDTA]. DNA was extracted from seeds in a similar way except for grinding, which was done in an Eppendorf tube immersed in liquid nitrogen, using a plastic pestle and lower reagent volume [250 $\mu$ l extraction buffer, $200 \mu \mathrm{l}$ chloroform:isoamyl alcohol (24:1 v/v), $170 \mu \mathrm{l}$ isopropanol, $170 \mu \mathrm{l} 70 \%$ ethanol, $10 \mu \mathrm{l}$ TE buffer]. After isolation,
DNA quality was checked by gel electrophoresis. Samples with low DNA concentration were eliminated.

\section{$D N A$ amplification and separation}

To analyze the $R$. acetosa and $R$. thyrsiflorus samples we used RAY-f (5'-ACTCG AATGTAAGCATTTGGTCCTA-3') and RAY-r (5'-ACTACACGATTGTCCATAAAGTG GA-3') primers developed by Korpelainen (2002). The PCR reaction mixture $(20 \mu \mathrm{l}$ total volume) contained $10 \mathrm{mM}$ Tris$-\mathrm{HCl}$ (pH 8.8), $50 \mathrm{mM} \mathrm{KCl}, 0.08 \% \mathrm{P} 40,2.5 \mathrm{mM} \mathrm{MgCl}_{2}$, $0.25 \mathrm{mM}$ dNTPs, $0.5 \mathrm{mM}$ of each primer, $1 \mathrm{U}$ Taq DNA Polymerase (Fermentas) and $100 \mathrm{ng}$ template DNA. Amplifications were performed using the following program: initial denaturation step at $94^{\circ} \mathrm{C}$ for 4 min.; 30 cycles consisting of denaturation step at $94^{\circ} \mathrm{C}$ for $1 \mathrm{~min}$., primer annealing step at $60^{\circ} \mathrm{C}$ for $45 \mathrm{~s}$ and primer extending step at $72^{\circ} \mathrm{C}$ for $1 \mathrm{~min} 30 \mathrm{~s}$; and final extending step at $72^{\circ} \mathrm{C}$ for $8 \mathrm{~min}$. The PCR products were separated in $1 \%$ agarose gel with ethidium bromide.

Amplification with primers R730-A (5'-CTCGGACCAATTATCTCAT-3') and R730-B (5'-CATTATTTG GGAGCCGAT-3') (Navajas-Peréz et al. 2005) was carried out to verify template DNA quality. The reaction mixture and program were the same as described above except for the temperature of the primer annealing step $\left(55^{\circ} \mathrm{C}\right)$.

To prevent false sex scorings we reexamined seed samples of $R$. acetosa with the use of primers UGR08-F (CCAATTGGTCTCAACTAGAACA) and UGR08-R (TGTTATAGGTTTTGGACTGCCA), specific for the male-specific sequence RAYSII in this species (Mariotti et al. 2009). PCR amplification and visualization were conducted as for the RAY-f and RAY-r primers.

\section{RESULTS}

\section{R. thyrsiflorus}

PCR with primers RAY-f and RAY-r was carried out using DNA from leaves of 10 male and 10 female plants to check whether these primers are male-specific in this species (Fig. 1a). The approximately 930 bp PCR product of this reaction was obtained for all males. A DNA band of similar length was also observed in some females, but there was a clear difference in the intensity of the amplified bands between the sexes. The situation was the same for the analyzed seeds (Fig. 1b). Based on the observed differences we tested the sex of 100 seeds from each of the two populations.

TABLE 1. Seed sex ratios of R. thyrsiflorus and R. acetosa.

\begin{tabular}{|c|c|c|c|c|c|c|c|c|}
\hline Species & & & $\mathrm{N}$ & $\mathrm{F}$ & M & $\chi^{2}$ & $\mathrm{FF}$ & M:F \\
\hline \multirow[t]{3}{*}{ R. thyrsiflorus } & Rudawa (S. Poland) & & 100 & 58 & 42 & $2.56^{n s}$ & 0.58 & $1: 1.38$ \\
\hline & Przeginia (S. Poland) & & 100 & 60 & 40 & $4.00^{*}$ & 0.60 & $1: 1.50$ \\
\hline & & total: & 200 & 118 & 82 & $6.78^{* *}$ & 0.59 & $1: 1.44$ \\
\hline \multirow{3}{*}{ R. acetosa } & Dobranowice (N. Poland) & & 100 & 65 & 35 & $9.00^{* * *}$ & 0.65 & $1: 1.86$ \\
\hline & Karwia (N. Poland) & & 100 & 63 & 37 & $6.76^{* * *}$ & 0.63 & $1: 1.70$ \\
\hline & & total: & 200 & 128 & 72 & $15.68^{* * * *}$ & 0.64 & $1: 1.78$ \\
\hline
\end{tabular}

$\mathrm{N}$ - number of analyzed seeds; $\mathrm{F}$ - number of female seeds; $\mathrm{M}$ - number of male seeds; $\chi^{2}-$ Chi-square test result $\left({ }^{*} \mathrm{P}<0.5 ;{ }^{* *} \mathrm{P}<0.2 ;{ }^{* * *} \mathrm{P}<0.01 ;{ }^{* * * *} \mathrm{P}<0.001\right.$; $n s$ - non significant); FF - frequency of females expressed as proportion of females to total (according to Korpelainen 2002); M:F - sex ratio expressed as 1:F/M (according to Rychlewski and Zarzycki 1975). 

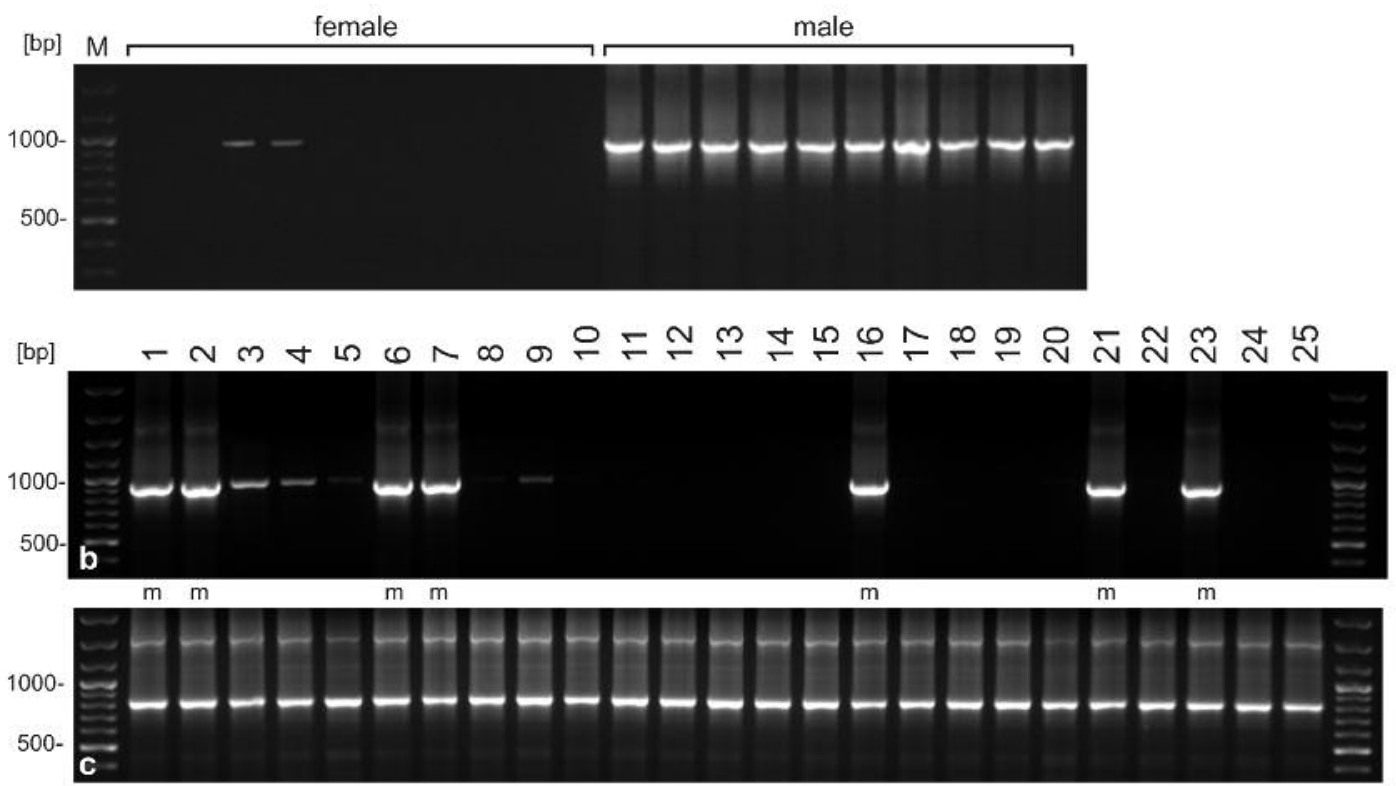

Fig. 1. PCR products in R. thyrsiflorus: a - DNA from leaves of flowering plants (RAY-f and RAY-r primers); $\mathrm{b}, \mathrm{c}$ - DNA from 25 seeds (b - RAY-f and RAY-r primers; c - R730-A and R730-B primers); M - 100 bp molecular weight markers.
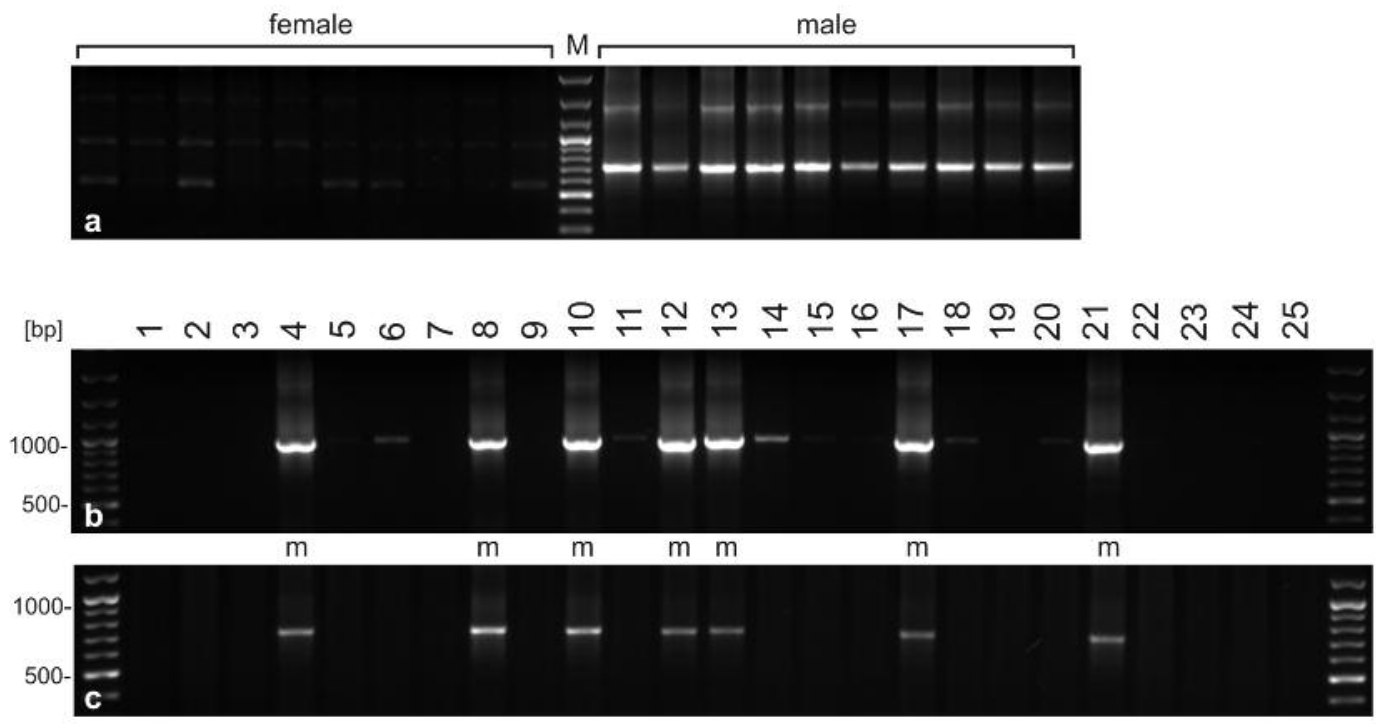

Fig. 2. PCR products in R. acetosa: a - DNA from leaves of flowering plants (UGR08-F and UGR08-R primers); b, c - DNA from 25 seeds (b - RAY-f and RAY-r primers; $\mathrm{c}$ - UGR08-F and UGR08-R primers); M - 100 bp molecular weight markers.

Among the sexed seeds we found $58 \%$ females in the first population and $60 \%$ females in the second (Table 1). The sex ratio of all analyzed seeds $(1: 1.44)$ differed significantly from the $1: 1$ ratio $\left(\chi^{2}\right.$ test, $\left.\mathrm{P}<0.02\right)$.

For the analyzed DNA samples we performed PCR with R730-A and R730-B primers, which amplify the repetitive RAE730 sequence located on Rumex autosomes (Shibata at al. 2000). We obtained PCR products for all tested seeds, showing that the DNA templates used for gender determination were of good quality (Fig. 1c).

\section{R. acetosa}

PCR with RAY-f and RAY-r primers carried out on DNA from $R$. acetosa leaves showed products in all male and some female plants. As in R. thyrsiflorus, the band intensity differed between males and females (data not shown).

Among the sexed seeds we found $65 \%$ females in the first population and $63 \%$ females in the second. The calcu- lated sex ratios in the analyzed seed samples $(1: 1.86$, $1: 1.70)$ deviated significantly from the $1: 1$ ratio $\left(\chi^{2}\right.$ test, $\mathrm{P}<0.001)$ and were higher than in $R$. thyrsiflorus (Table 1 ).

Because our studies with RAY-f and RAY-r primers produced results differing from those reported by Korpelainen (2002), we rechecked the sex of the seeds with a different pair of sex-specific primers, UGR08-F and UGR08-R. According to Mariotti et al. (2009), these primers are specific for the repetitive RAYSII sequence located on the Y1 chromosome of $R$. acetosa. The $700 \mathrm{bp}$ band generated by these primers was observed only in male leaves (Fig. 2a), and was produced exclusively in seeds identified as male with the use of RAY-f and RAY-r primers (Fig. 2b, c). Thus, the established number of female seeds was the same for RAY and UGR primers (128 out of 200 seeds). PCR with R730-A and R730-B primers confirmed the good quality of the template DNA from all analyzed seeds. 


\section{DISCUSSION}

We confirmed the usefulness of the RAY-f and RAY-r primers developed by Korpelainen (2002) for sexing seeds of $R$. acetosa, and showed that the same primers are also effective for determining gender in R. thyrsiflorus. Unlike Korpelainen (2002), we observed the amplified product in females as well. Fortunately, the bands from male templates were much more intense than those from female DNA, so we could rely on these primers to identify sex.

Our experiment suggests that UGR08-F and UGR08-R primers (Mariotti et al. 2009), producing DNA fragments only in male $R$. acetosa plants, may be more useful for molecular sexing of this species. With the appropriate checks, these primers may also find application in other Rumex species.

Both analyzed species showed a female-biased primary sex ratio, a result consistent with the view that the sex ratio is aberrant in Rumex seeds (Rychlewski and Zarzycki 1986; Stehlik and Barrett 2005). The seed sex ratios differed between the species, with substantially greater female bias in $R$. acetosa than in $R$. thyrsiflorus. The differences in primary sex ratio between two populations of the same species were small. Seed samples from two very distant (ca. $600 \mathrm{~km}$ ) populations of $R$. acetosa showed similar, highly female-biased sex ratios.

Though closely related, the two taxa differ not only in flowering time but also in nuclear DNA amount (7\% difference) and in the location of repetitive sequences within the genome (Joachimiak, unpublished data). The observed sex ratio difference are probably attributable at least in part to genetic differences between the two species.

The observed sex ratios in ungerminated seeds are similar to findings reported for R. nivalis, in which female bias was clearly demonstrated (Stehlik and Barrett 2005), and differ from those given by Korpelainen (2002) for six Finnish populations of $R$. acetosa, in which the primary sex ratio did not differ significantly from the 1:1 ratio. In Polish populations of this species the female sex ratio bias is not only statistically significant but also relatively high. The reason for this difference may be very difficult to determine because all the causative pre- and postzygotic factors may be both genetically and environmentally conditioned.

Interestingly, $R$. acetosa and $R$. nivalis showed femalebiased 'microgametophytic' sex ratios (Błocka-Wandas et al. 2007; Stehlik et al. 2007). The quantitative predominance of female-determining $(\mathrm{A}+\mathrm{X})$ over male-determining $\left(A+Y_{1} Y_{2}\right)$ pollen grains in these species was small but significant. The degree of microgametophytic female bias in $R$. acetosa $(55 \%)$ is too small to account for the bias observed in seeds (64\%). Two post-pollination mechanisms might be implicated in the increased female bias in seeds: certation and/or abortion of developing male seeds. This issue requires further study.

All suggested mechanisms determining female bias in seeds (predominance of $\mathrm{A}+\mathrm{X}$ pollen grains, certation, abortion of developing male seeds) might be explainable by genetic degeneration of plant Y chromosomes (Smith 1963; Żuk 1970; Rychlewski and Zarzycki 1975; Stehlik and Barret 2005). That possibility should be treated with caution, because currently there is little evidence for genetic degeneration of plant Y chromosomes (Grabowska-Joachi- miak and Joachimiak 2002; Armstrong and Filatov 2008), and female-biased sex ratios have also been observed in dioecious plants without sex chromosomes (Obeso 2002). It would be interesting to examine the seed sex ratio in $\mathrm{Hu}$ mulus japonicus, a plant having the same dosage sex-chromosome system (Parker and Clark 1991; GrabowskaJoachimiak et al. 2006) and showing female bias at flowering stage (Joachimiak unpubl.). Unfortunately, it is not yet possible due to the lack of sex-specific molecular markers in this species.

\section{LITERATURE CITED}

ARMSTRONG S.J., FILATOV D.A. 2008. A cytogenetic view of sex chromosome evolution in plants. Cytogen. Genome Res. 120: 241-246.

BŁOCKA-WANDAS M., SLIWIŃSKA E., GRABOWSKA-JOACHIMIAK A., MUSIAŁ K., JOACHIMIAK A.J. 2007. Male gametophyte development and two different DNA classes of pollen grains in Rumex acetosa L., a plant with an $\mathrm{XX} / \mathrm{XY}_{1} \mathrm{Y}_{2}$ sex chromosome system and female-biased sex ratio. Sex. Plant Repr. 20: 171-180.

CORRENS C. 1928. Bestimmung, Vererbung und Verteilung des Geschlechtes bei den höheren Pflanzen. Bornträger, Berlin, Germany.

GAWAL N.J., JARRET R.L. 1991. A modified CTAB DNA extraction procedure for Musa and Ipomoea. Plant Mol. Biol. Rep. 9: 262-266.

GRABOWSKA-JOACHIMIAK A., JOACHIMIAK A. 2002. C-banded karyotypes of two Silene species with heteromorphic sex-chromosomes. Genome 45: 243-252.

GRABOWSKA-JOACHIMIAK A., SLIWINSKA E., PIGUŁA M., SKOMRA U., JOACHIMIAK A.J. 2006. Genome size in Humulus lupulus L. and H. japonicus Siebold \& Zucc. (Cannabaceae). Acta Soc. Bot. Pol. 75: 207-214.

KORPELAINEN H. 2002. A genetic method to resolve gender complements investigations on sex ratios in Rumex acetosa. Mol. Ecol. 11: 2151-2156.

MARIOTTI B., MANZANO S., KEJNOVSKY E., VYSKOT B. JAMILENA, M. 2009. Accumulation of Y-specific satellite DNAs during the evolution of Rumex acetosa sex chromosomes. Mol. Gen. Genom. 281: 249-259.

MOSIOŁEK M., PASIERBEK P., MALARZ J., MOŚ M., JOACHIMIAK A.J. 2005. Rumex acetosa Y chromosomes: constitutive or facultative heterochromatin? Folia Histochem. Cytobiol. 43: 161-167.

NAVAJAS-PERÉZ R., DE LA HERRAN R., JAMILENA M., LOZANO R., RUIZRUIZ REJÓN M., GARRIDO-RAMOS M.A. 2005. Reduced rates of sequence evolution of Y-linked satellite DNA in Rumex (Polygonaceae). J. Mol. Evol. 60: 391-399.

NAVAJAS-PERÉZ R., SCHWARZACHER T., DE LA HERRÁN R., RUIZ REJÓN C., RUIZ REJÓN M., GARRIDO-RAMOS M.A. 2006. The origin and evolution of the variability in a Y-specific satellite-DNA of Rumex acetosa and its relatives. Gene 368: 61-71.

OBESO J.R. 2002. The cost of reproduction in plants. New Phytol. 155: 321-348.

PARKER J.S., CLARK M.S. 1991. Dosage sex-chromosome systems in plants. Plant Sci. 80: 79-92.

RYCHLEWSKI J., ZARZYCKI K. 1975. Sex ratio in seeds of Rumex acetosa L. as a result of sparse or abundant pollination. Acta Biol. Cracov. Ser. Bot. 18: 101-113.

RYCHLEWSKI J., ZARZYCKI K. 1981. Sex ratio in seeds of Rumex thyrsiflorus Fing. from European and Canadian populations. Acta Biol. Cracov. Ser. Bot. 23: 97-105 
RYCHLEWSKI J., ZARZYCKI K. 1986. Genetical and ecological mechanisms regulating the sex ratio in populations of Rumex thyrsiflorus Fingerh. (Polygonaceae). Bull. Geobot. Inst. ETH 87: 132-140

SHIBATA F., HIZUME M., KUROKI Y. 1999. Chromosome painting of $\mathrm{Y}$ chromosomes and isolation of a $\mathrm{Y}$ chromosomespecific repetitive sequence in the dioecious plant Rumex acetosa. Chromosoma 108: 266-270.

SHIBATA F., HIZUME M., KUROKI Y. 2000. Molecular cytogenetic analysis of supernumerary heterochromatic segments in Rumex acetosa. Genome 43: 391-397.

SMITH B.W. 1963. The mechanism of sex determination in Rumex hastatulus. Genetics 48: 1265-1288.

STEHLIK I., BLATTNER F.R. 2004. Sex-specific SCAR markers in the dioecious plant Rumex nivalis (Polygonaceae) and implications for the evolution of sex chromosomes. Theor. Appl. Genet. 108: 238-242.

STEHLIK I., BARRETT S.C.H. 2005. Mechanisms governing sex-ratio variation in dioecious Rumex nivalis. Evolution 59: 814-825.
STEHLIK I., BARRETT S.C.H. 2006. Pollination intensity influences sex ratios in dioecious Rumex nivalis, a wind-pollinated plant. Evolution 60: 1207-1214.

STEHLIK I., KRON P., BARRETT S.C.H. HUSBAND B.C. 2007. Sexing pollen reveals female bias in a dioecious plant. New Phytol. 175: 185-194.

STEHLIK I., FRIEDMAN J., BARRETT S.C.H. 2008. Environmental influence on primary sex ratio in dioecious plant. Proc. Nat. Acad. Sci. USA 105: 10847-10852.

ZARZYCKI K., RYCHLEWSKI J. 1972. Sex ratios in Polish natural populations and in seedling samples of Rumex acetosa $\mathrm{L}$. and $R$. thyrsiflorus Fing. Acta Biol. Cracov. Ser. Bot. 15: 135-151 .

ŻUK J. 1963. An investigation on polyploidy and sex-determination within the genus Rumex. Acta Soc. Bot. Pol. 32: 5-72.

ŻUK J. 1970. Structure and function of sex chromosomes in Rumex thyrsiflorus. Acta Soc. Bot. Pol. 39: 539-564. 
